\title{
A Study of Hospital Infection Control Program against Normative Weighted Criteria at a Large Public Hospital
}

\author{
1Jitender Mehta, ${ }^{2}$ Sanjay Arya, ${ }^{3}$ Sunil Kant, ${ }^{4}$ Shakti Kumar Gupta
}

\begin{abstract}
Hospital infection control programs are important for prevention and control of hospital acquired infection in a healthcare facility. An evaluatory study was done to measure the quality dimensions of hospital infection control program in a public hospital to compare the program implementation in different speciality centers against the normative weighted criteria developed by Gupta and Kant (2002). Result showed variations in infection control program activities in various speciality centers. A centralized administration of infection control program and emphasis on more training and education is recommended.
\end{abstract}

Keywords: Hospital infection control program, Normative weighted criteria, Healthcare associated (nosocomial) infections.

How to cite this article: Mehta J, Arya S, Kant S, Gupta SK. A Study of Hospital Infection Control Program against Normative Weighted Criteria at a Large Public Hospital. Int J Res Foundation Hosp Healthc Adm 2014;2(2):130-132.

Source of support: Nil

Conflict of interest: None

\section{INTRODUCTION}

\section{Hospital Infection Control Program}

Infection control programs in healthcare settings are important component of overall healthcare system, because the healthcare associated (nosocomial) infections (HAI) represent one of the most common complications of healthcare and are widely recognized as a major public health problem. Hospital infection control programs are, primarily, dedicated to assisting the public health services-state and local health authorities, hospitals and other professional

\footnotetext{
${ }^{1}$ Resident Administrator, ${ }^{2}$ Additional Professor, ${ }^{3}$ DDG (OPP) ${ }^{4}$ Medical Superintendent

1,2Department of Hospital Administration, All India Institute of Medical Sciences, New Delhi, India

${ }^{3} \mathrm{HHQ}$ of Ministry of Defence, New Delhi, India

${ }^{4} \mathrm{Dr}$ RP Centre for Ophthalmic Sciences, All India Institute of Medical Sciences, New Delhi, India

Corresponding Author: Shakti Kumar Gupta, Medical Superintendent and Faculty, Department of Hospital Administration and Dr RP Centre for Ophthalmic Sciences, All India Institute of Medical Sciences, New Delhi, India, e-mail: shakti810505@gmail.com
}

organizations in the prevention and control of nosocomial infections in the hospitals.

To be effective the infection control program should include the following components:

- Organized surveillance and control activities.

- One infection control practitioner for every major health facility.

- A trained hospital epidemiologist.

- A system for reporting surgical wound infection rates and other infections back to the practicing surgeons and physicians.

- Continuing education of medical staff.

- Control of infectious disease outbreaks.

- Protection of employees from infection.

- Advice on new products, devices and procedures pertinent to infection control.

- Instructions on all necessary control measures in the event of an outbreak or other infection control emergency.

\section{QUALITY DIMENSIONS IN HOSPITAL INFECTION CONTROL}

The quality of a hospital's (or healthcare centre's) infection control program is a reflection of the overall standard of care provided by that institution. Good infection control programs reduce nosocomial infections, length of stay in the hospital, and costs associated with hospitalization. Hospital infection control activities need to have well defined policy and guidelines for quality control and needs to be monitored against standard guidelines with defined criteria. Various National and International agencies has prescribed guidelines for infection control quality parameters. Some of the popular guidelines followed in India are guidelines by various accreditation agencies like national accreditation board for hospitals and healthcare providers (NABH), India (as per NABH accreditation standards manual, 2nd edition 2007) [Chapter 5: hospital infection control (HIC) $]^{1}$ and joint commission international (JCI, 4th edition, health care facilty management standards: prevention and control of standards). ${ }^{2}$ A popular questionnaire was developed and published by Gupta and Kant in 2002 to assess the quality parameters for infection control (Shakti K Gupta, Sunil Kant in journal of the academy of hospital administration vol. 14, no. 1 (2002-01-2002-06) (Article: 'Quality Dimensions in HIC). ${ }^{3}$ The questionnaire suggested certain normative 
weighted criteria. A patient or his relatives, wishing to utilize a healthcare institutions should have a known predetermined quality standard available for guidance.

The questionnaire defines the parameters as following:

\section{Structure criteria}

Has a well enunciated hospital infection control committee 5 incorporating a hospital administrator, microbiologist, clinician and a nursing administrator?

Has a functional hospital infection team incorporating 5 microbiologist, nursing staff, housekeeping staff and an epidemiologist?

There exists specific job description for each personnel of 5 above committee/team.

Physical facilities are conducive for prevention of hospital 5 infection such as ward design bed spacing, flooring, isolation rooms, drainage, etc.

House keeping services and biomedical waste management 5 are appropriately incorporated in the hospital infection control program

\section{Procedures and policies}

Has well enunciated principles of hospital infection control 5 such as to eliminate sources of infection, and routes of spread, surveillance for infection, investigations during outbreaks, etc.

Existence of comprehensive standing operative procedures 5 (SOPs) for hospital infection control program including disinfection and sterilization of equipment, universal precautions, protective vaccinations vis hepatitis, tetanus and gas gangrene, use of disposables, housekeeping disinfectants, handing of specimen's barrier and reverse barrier nursing.

Has a functional antibiotic policy?

Has an interactive interdepartmental coordination in 5 reference to hospital infection control program including services, such as housekeeping, laundry, central sterile supply department (CSSD) and dietary?

Process criteria

Scientific data collection and analysis related to hospital 5 infection control program during surveillance and investigation for HAl. Comprehensive documentation exists.

Scientific sample collection and laboratory investigation 5 molecular methods are being utilized in laboratory investigations for $\mathrm{HAl}$.

Internal and external audit for laboratory investigations. 5 Awareness levels among various staff personnel regarding 5 HAl.

Training and reorientation programs being conducted related 5 to HAI.

Cost evaluation analysis for antibiotic usage, $\mathrm{HAl}$, etc. 5 Activities aimed for achievement of continuous quality 5 improvement (CQI).

\section{Outcome}

Hospital infection rate viz-a-viz incidence at local/national/ 10 international levels.

Satisfactory internal and external laboratory audit. 5

Staff and patient satisfaction.

Total credit points

The parameters given in the questionnaire have been weighted as their related importance. The parameters have been clubbed as per their structure, process or outcome affiliation. The mentioned weighted credits are the maximum that may be granted to a particular parameter.

The grading may be done as follows:

\begin{tabular}{|c|c|c|c|}
\hline Credit point & & Gradings & \\
\hline $80-100$ & A++ & Outstanding & These are suggested \\
\hline $70-80$ & $A+$ & Very Good & credit parameters and \\
\hline $60-70$ & A & Good & gradings. \\
\hline $50-60$ & B & Average & These may be modified \\
\hline Below & $\mathrm{C}$ & Below average & $\begin{array}{l}\text { appropriately for various } \\
\text { healthcare institutions }\end{array}$ \\
\hline
\end{tabular}

The Present Study

An evaluatory study was done to assess the quality prameters of hospital infection control program in superspeciality centers of All India Institute of Medical Sciences, New Delhi. A comparative study against the back drop of the Gupta and Kant questionnaire was done.

Based on the normative weighted criteria, the observations were made as shown in Table 1 (normative weighted credit criteria and credit points assigned).

\section{RESULTS AND CONCLUSION}

The study brings out the following results:

\begin{tabular}{|c|c|c|c|c|c|}
\hline & $\begin{array}{l}\text { Main } \\
\text { AlIMS }\end{array}$ & $\begin{array}{l}\text { CN } \\
\text { center } \\
\text { (Neuro.) }\end{array}$ & $\begin{array}{l}\text { CN } \\
\text { center } \\
\text { (Cardio.) }\end{array}$ & $\mathrm{IRCH}$ & RPCOS \\
\hline $\begin{array}{l}\text { Credit points } \\
\text { obtained } \\
\text { (Out of } \\
\text { maximum } \\
\text { score of 100) }\end{array}$ & 90 & 50 & 20 & 40 & 75 \\
\hline Grading given & $\begin{array}{l}\text { A++ } \\
\text { Out- } \\
\text { standing }\end{array}$ & $\begin{array}{l}\text { B } \\
\text { Average }\end{array}$ & $\begin{array}{l}\mathrm{C} \\
\text { Below } \\
\text { average }\end{array}$ & $\begin{array}{l}\text { C } \\
\text { Below } \\
\text { average }\end{array}$ & $\begin{array}{l}\text { A+ } \\
\text { Very } \\
\text { good }\end{array}$ \\
\hline
\end{tabular}

From the study, it is observed that there is variable conformance toward infection control practices and official regulatory compliance from center to center in AIIMS. While AIIMS main hospital stands outstanding in terms of compliance, some of the centers have still to come to the level of average.

\section{RECOMMENDATIONS}

To bring best infection control practices in place and strengthen the infection control program, following are recommended:

1. Establishment of a centralized hospital infection control committee: In the absence of a central hospital infection control committee, the prescripts are laid down most of the time by the local committee in the speciality center. Institute needs to have a centralized infection control committee for centralized administration of hospital infection control program.

2. Education and training: All the centers of AIIMS need to devise education and training program for infection control practices on a continuous basis. Practical 
Table 1: Normative weighted criteria and credit points assigned

\begin{tabular}{|c|c|c|c|c|c|c|c|}
\hline $\begin{array}{l}\text { Sl. } \\
\text { no. }\end{array}$ & Criteria & $\begin{array}{l}\text { Max. } \\
\text { score }\end{array}$ & Main AlIMS & $\begin{array}{l}\text { CN } \\
\text { center } \\
\text { (Neuro) }\end{array}$ & $\begin{array}{l}\text { CN } \\
\text { center } \\
\text { (Cardio) }\end{array}$ & $\mathrm{IRCH}$ & RPCOS \\
\hline 1. & $\begin{array}{l}\text { Has a well-enunciated hospital infection control committee incorpo- } \\
\text { rating a hospital administrator, microbiologist, clinician and a nursing } \\
\text { administrator? }\end{array}$ & 5 & 5 & - & - & - & 5 \\
\hline 2. & $\begin{array}{l}\text { Has a functional hospital infection team incorporating microbiologist, } \\
\text { nursing staff, housekeeping staff and an epidemiologist? }\end{array}$ & 5 & 5 & - & - & - & 5 \\
\hline 3. & $\begin{array}{l}\text { There exists specific job description for each personnel of above } \\
\text { committee/team. }\end{array}$ & 5 & 5 & - & - & - & 5 \\
\hline 4. & $\begin{array}{l}\text { Physical facilities are conducive for prevention of hospital infec- } \\
\text { tion, such as ward design bed spacing, flooring, isolation rooms, } \\
\text { drainage, etc. }\end{array}$ & 5 & 5 & 5 & 5 & 5 & 5 \\
\hline 5. & $\begin{array}{l}\text { Housekeeping services and biomedical waste management are } \\
\text { appropriately incorporated in the hospital infection control program. }\end{array}$ & 5 & 5 & 5 & - & 5 & 5 \\
\hline \multicolumn{8}{|c|}{ Procedure and policies } \\
\hline 1. & $\begin{array}{l}\text { Has well enunciated principles of hospital infection control, such as } \\
\text { to eliminate sources of infection, and routes of spread, surveillance } \\
\text { for infection, investigations during outbreaks, etc? }\end{array}$ & 5 & 5 & 5 & 5 & 5 & 5 \\
\hline 2. & $\begin{array}{l}\text { Existence of comprehensive SOPs for program including disinfection } \\
\text { and sterilization of equipment, universal precautions, protective vacci- } \\
\text { nations vis hepatitis, tetanus and gas gangrene, use of disposables, } \\
\text { housekeeping disinfectants, handing of specimens barrier and reverse } \\
\text { barrier nursing. }\end{array}$ & 5 & 5 & 5 & 5 & 5 & 5 \\
\hline 3. & Has a functional antibiotic policy? & 5 & - & - & - & - & - \\
\hline 4. & $\begin{array}{l}\text { Has an interactive interdepartmental coordination in reference to } \\
\text { hospital infection control program including services, such as house- } \\
\text { keeping, laundry, CSSD and dietary? }\end{array}$ & 5 & 5 & 5 & - & & 5 \\
\hline \multicolumn{8}{|c|}{ Process criteria } \\
\hline 1. & $\begin{array}{l}\text { Scientific data collection and analysis related to hospital infec- } \\
\text { tion control program during surveillance and investigation for HAI. } \\
\text { Comprehensive documentation exists. }\end{array}$ & 5 & 5 & 5 & - & 5 & 5 \\
\hline 2. & $\begin{array}{l}\text { Scientific sample collection and laboratory investigation molecular } \\
\text { methods are being utilized in laboratory investigations for HAl. }\end{array}$ & 5 & 5 & 5 & 5 & 5 & 5 \\
\hline 3. & Internal and external audit for laboratory investigations. & 5 & - & - & - & - & - \\
\hline 4. & Awareness levels among various staff personnel regarding HAI. & 5 & 5 & - & - & 5 & 5 \\
\hline 5. & Training and reorientation programs being conducted related to HAI. & 5 & 5 & - & - & -- & 5 \\
\hline 6. & Cost evaluation analysis for antibiotic usage, $\mathrm{HAl}$, etc. & 5 & - & - & - & - & - \\
\hline 7. & Activities aimed for achievement of CQI. & 5 & 5 & 5 & - & - & 5 \\
\hline \multicolumn{8}{|c|}{ Outcome } \\
\hline 1. & $\begin{array}{l}\text { Hospital infection rate } \\
\text { viz-a-viz incidence at local/national/international levels. }\end{array}$ & 10 & 10 & 10 & - & - & - \\
\hline 2. & Satisfactory internal and external laboratory audit. & 5 & 5 & - & - & - & - \\
\hline 3. & Staff and patient satisfaction. & 5 & 5 & 5 & - & 5 & 5 \\
\hline \multicolumn{2}{|c|}{ Total credit points } & 100 & 90 & 50 & 20 & 40 & 75 \\
\hline \multicolumn{2}{|c|}{ Grading } & & $\begin{array}{l}\text { A++ } \\
\text { Outstanding }\end{array}$ & $\begin{array}{l}\text { B } \\
\text { Average }\end{array}$ & $\begin{array}{l}\text { C } \\
\text { Below } \\
\text { average }\end{array}$ & $\begin{array}{l}\text { C } \\
\text { Below } \\
\text { average }\end{array}$ & $\begin{array}{l}\text { A+ } \\
\text { Very } \\
\text { good }\end{array}$ \\
\hline
\end{tabular}

training of every member of the hospital related to care is important and it needs to be incorporated early at the time of member joining the institute. It is generally observed that there is less compliance toward infection control practices among doctors (residents as well as faculty) in comparison to other workers of hospital, e.g. nurses, paramedical and other staff.

\section{REFERENCES}

1. NABH Accreditation Standards Manual 2007. Quality Council of India, New Delhi, India.

2. JCI Accreditation Standards for Hospitals. 4th ed. July 2010, JCI, Oak Brook, Illinois 60523, USA.

3. Gupta SK, Kant S. Quality dimensions in hospital infection control. J Acad Hosp Adminis. AHA, Noida, India, (2002-012002-06);14(1). 